\title{
RELEVANSI MATERI MATA KULIAH KEAHLIAN OTOMOTIF DENGAN MATERI MATA PELAJARAN KOMPETENSI KEAHLIAN TEKNIK KENDARAAN RINGAN TERHADAP MATERI UJI KOMPETENSI KEAHLIAN STANDAR BSNP
}

\author{
Agung Novianto $^{1}$, Amay Suherman ${ }^{2}$, Ariyano $^{3}$ \\ Departemen Pendidikan Teknik Mesin \\ Universitas Pendidikan Indonesia \\ Jl. Dr. Setiabudhi No. 207 Bandung 40154 \\ noviagung46@gmail.com
}

\begin{abstract}
ABSTRAK
Tujuan penelitian ini adalah untuk mengetahui relevansi materi MKK otomotif dengan materi mata pelajaran kompetensi keahlian teknik kendaraan ringan (TKR), dan materi UKK BSNP. Objek dari penelitian ini adalah materi pembelajaran pada kurikulum DPTM UPI, kurikulum SMK, dan materi UKK BSNP. Penelitian ini menggunakan metode evaluasi model discrepancy. Instrumen yang digunakan berupa dokumentasi, lembar wawancara dan angket. Hasil penelitian menunjukkan bahwa Materi MKK otomotif telah relevan dan memenuhi keseluruhan materi mata pelajaran kompetensi keahlian TKR sebanyak 173 materi, dan 130 materi UKK TKR I, II, dan III. Materi mata pelajaran kompetensi keahlian TKR SMK telah memenuhi materi UKK paket I dan II, namun belum memenuhi materi UKK TKR paket III, sebanyak 10 materi.
\end{abstract}

Kata kunci: relevansi, kurikulum, kompetensi, otomotif.

\begin{abstract}
The purpose of this study was carried out to determine the relevance of the material to the material MKK automotive subject competency light vehicle engineering, and material UKK BSNP. The object of this research is learning material on DPTM UPI curriculum, vocational curriculum, and materials UKK BSNP. This study uses a model discrepancy evaluation. Instruments used in the form of documentation, interviews and questionnaire sheet. The results of this study found that the material was relevant and MKK automotive meets overall subject matter competency TKR, 173 material, and 130 materials UKK TKR I, II, and III, while the material Subjects Vocational Skills Competency TKR has met the material UKK package I and II, but does not meet the UKK material TKR package III.
\end{abstract}

Keywords: relevance, curriculum, competences, automotive

\footnotetext{
${ }^{1}$ Mahasiswa Departemen Pendidikan Teknik Mesin FPTK UPI

${ }^{2}$ Dosen Departemen Pendidikan Teknik Mesin FPTK UPI

${ }^{3}$ Dosen Departemen Pendidikan Teknik Mesin FPTK UPI
} 


\section{PENDAHULUAN}

Departemen Pendidikan Teknik Mesin sebagai lembaga yang menyiapkan tenaga pendidik SMK, harus membekali peserta didiknya, minimal sesuai dengan kompetensi yang dibutuhkan oleh SMK, baik dari segi kompetensi keahlian maupun dari kompetensi kependidikannya. Kompetensi keahlian yang harus dimiliki minimal harus sesuai dengan kompetensi yang digunakan di SMK, sesuai dengan standar kompetensi profesional tenaga pendidik. Salah satu caranya dengan merujuk pada kurikulum SMK, saat melakukan pengembangan kurikulum di DPTM. Merujuk kurikulum yang dimaksud bukan menyamakan semua tanpa ada pengembangan, namun merujuk yang dimaksud adalah, hanya sebagai patokan minimal kompetensi yang harus ada di dalam kurikulum DPTM.

Kurikulum memiliki empat komponen utama, yaitu tujuan, isi/materi, proses, dan evaluasi (Nasution, 2003). Pembekalan yang diberikan kepada peserta didik DTPM dengan kompetensi keahlian yang sesuai dengan kebutuhan SMK, lebih menitik beratkan pada komponen isi/materi kurikulum. Isi/materi pembelajaran di kurikulum DPTM minimal harus mencakup isi/materi pembelajaran di kurikulum yang digunakan SMK. Hal ini sesuai dengan salah satu prinsip pengembangan kurikulum UPI, yaitu prinsip koherensi antar konten kurikulum.. Berdasarkan prinsip koherensi, seharusnya memang terbangun keterkaitan/relevansi kurikulum antara kurikulum bidang studi (DPTM) dengan kebutuhan pembelajaran di sekolah, dengan adanya pemetaan sekuen isi/materi pembelajaran antara DPTM dengan SMK. Hal ini untuk mendukung kesiapan mahasiswa melaksanakan Program Praktek pengalaman Lapangan (PPL).

Kenyataan di lapangan, pemetaan sekuen isi/materi pembelajaran antara DPTM dengan SMK belum ada. Kesesuaian materi kurikulum SMK dan Uji Kompetensi disesuaikan dan materi kurikulum SMK dengan UPI tidak tahu. Sangat memungkinkan bahwa, isi/materi pembelajaran di DPTM belum mencakup sepenuhnya isi/materi pembelajaran di SMK.

Adanya program PPL, yang mengharuskan mahasiswa untuk ikut dalam kegiatan di sekolah, khususnya proses belajar mengajar di SMK, menuntut perlunya mahasiswa untuk memahami materi-materi pembelajaran yang ada di SMK. Penguasaan materi pembelajaran bertujuan agar mahasiswa PPL tidak lagi mengalami kesulitan tentang materi yang akan diajarkan, dan dapat menyampaikan materi pembelajaran dengan baik. Kondisi ini berarti perlu adanya pemantauan kurikulum yang digunakan SMK, sehingga pembekalan materi yang harus dikuasai mahasiswa DPTM sesuai dengan yang dibutuhkan di SMK. 
Menyiapkan tenaga pendidik yang profesional tidak cukup hanya dengan memberikan bekal materi yang mencakup keseluruhan materi yang ada di SMK (khususnya materi keahlian otomotif), namun juga harus di uji dengan standar uji kompetensi yang di keluarkan oleh Badan Standar Nasional Pendidikan (BSNP), untuk menilai kemampuan/kompetensi, yang dimiliki oleh peserta didik dalam bidang keahlian yang digelutinya.

Kenyataan di lapangan bahwa, sebagian besar peserta didik DPTM belum melaksanakan uji kompetensi. Hambatan terbesar peserta didik tidak melaksanakan uji kompetensi adalah besarnya biaya yang dibutuhkan. Namun secara cakupan materi, hal ini dapat diminimalkan. Dengan melihat relevansi antara materi pembelajaran di DPTM dengan materi yang digunakan dalam uji kompetensi. Namun DPTM belum pernah membuat pemetaan materi, antara materi DPTM dengan materi uji kompetensi. Sehingga belum dapat diketahui apakah materi di DPTM sudah relevan dengan materi yang digunakan dalam uji kompetensi. Tujuan penelitian ini adalah untuk menghasilkan deskripsi relevansi materi antara MKK otomotif dengan materi mata pelajaran kompetensi keahlian teknik kendaraan ringan, dan dengan materi UKK BSNP. Selain itu juga menghasilkan deskripsi relevansi materi antara materi mata pelajaran kompetensi keahlian teknik kendaraan ringan, dengan materi UKK BSNP.

Kurikulum ialah suatu program pendidikan yang berisikan berbagai bahan ajar dan pengalaman belajar yang diprogramkan, direncanakan, dan dirancangkan secara sistemik atas dasar norma-norma yang berlaku yang dijadikan pedoman dalam proses pembelajaran bagi tenaga kependidikan dan peserta didik untuk mencapai tujuan pendidikan (Dakir, 2010). Kurikulum merupakan panduan yang digunakan untuk mencapai tujuan, pendapat ini juga sesuai dengan pengertian kurikulum menurut Undang-Undang Sisdiknas Nomor 20 Tahun 2003. Fungsi kurikulum terdiri dari empat fungsi yaitu: (1) fungsi pendidikan umum (common and general education), (2) fungsi suplementasi (suppleme-ntation), bermakna bahwa kurikulum sebagai alat pendidikan yang harus mampu memberikan pelayanan kepada setiap siswa sesuai dengan perbedaan kemampuan, minat, maupun bakat. (3) fungsi eksplorasi (exploration), dan (4) fungsi keahlian (specialization), bermakna bahwa kurikulum berfungsi untuk mengembangkan kemampuan anak sesuai dengan keahlian atas dasar minat dan bakatnya (Sanjaya, 2008).

Kurikulum selain memiliki fungsi, juga memiliki peran. Peranan konservatif, yaitu peranan kurikulum untuk mewariskan, mentransmisikan, dan menafsirkan nilai-nilai sosial dan budaya masa lampau yang tetap eksis dalam masyarakat (Hamalik, 2007). Peranan 
kritis dan evaluatif, yaitu peranan kurikulum untuk menilai dan memilih nilai-nilai sosialbudaya yang akan diwariskan kepada peserta didik berdasarkan kriteria tertentu. Peranan kreatif, yaitu peranan kurikulum untuk menciptakan dan menyusun kegiatan-kegiatan yang kreatif dan konstruktif sesuai dengan perkembangan peserta didik dan kebutuhan masyarakat.

Komponen isi/materi kurikulum adalah semua kegiatan dan pengalaman yang dikembangkan dan disusun dalam rangka mencapai tujuan pendidikan (Arifin, 2011). Materi pembelajaran (instructional materials) adalah pengetahuan, keterampilan, dan sikap yang harus dipelajari dan dimiliki peserta didik dalam rangka mencapai kemampuan/kompetensi yang telah ditentukan. Materi pembelajaran mencakup jenis, kedalaman, ruang lingkup (scope), dan urutan materi pembelajaran (squence) (Munir, 2010). Sekuen (sequence) berarti susunan atau urutan pengelompokan kegiatan atau langkah-langkah yang dilakukan dalam perencanaan kurikulum. Sekuens lebih mengetengahkan susunan materi pelajaran, ada beberapa cara untuk menyusun sekuens bahan ajar, yaitu: a) kronologis, b) kausal, c) struktural, d) logis dan psikologis, e) spiral, dan f) rangkaian kebelakang.

Perkembangan masyarakat dalam bidang ilmu dan teknologi, menuntut dunia pendidikan untuk melakukan penyesuaian guna memenuhi kebutuhan di masyarakat, salah satu cara yang dilakukan adalah dengan melakukan pengembangan kurikulum. Pengembanan kurikulum ialah "mengarahkan kurikulum sekarang ke tujuan pendidikan yang diharapkan, karena adanya berbagai pengaruh yang sifatnya positif yang datangnya dari luar atau dari dalam sendiri, dengan harapan agar peserta didik dapat menghadapi masa depannya dengan baik.

Pengembangan kurikulum terdapat prinsip, seperti yang disampaikan oleh bahwa, prinsip pengembangan kurikulum diklasifikasikan menjadi dua kategori, yaitu prinsip umum dan prinsip khusus. Prinsip mum pengembangan kurikulum terdiri dari Prinsip relevansi, prinsip fleksibilitas, prinsip kontinuitas, prinsip praktis dan efisien, dan prinsip efektivitas (Sukmadinata, 2009). Rambu-Ranbu Pengembangan Kurikulum Universitas Pendidikan Indonesia (UPI) Tahun 2013, prinsip pengembangan kurikulum UPI terdiri dari, pengembangan karakter budaya bangsa, keutuhan pendidikan akademik dan profesi, keterkaitan mengajar dan belajar, koherensi antar konten kurikulum, suasana dan kultur akademik, multikulturalisme dan kearifan lokal, pembaharuan dan berkesinambungan, fleksibilitas, kesetaraan gender, pendidikan inklusi, kesadaran lingkungan, dan demokrasi. 
Relevansi berarti kecocokan, bersangkut paut, berguna secara langsung, kaitan, hubungan. Relevansi ialah sesuatu sifat yang terdapat pada dokumen yang dapat membantu pengarang dalam memecahkan kebutuhan akan informasi. Revevansi artinya adanya kesatuan antara hasil pendidikan dengan tuntutan yang ada di masyarakat. Konsep relevansi memandang, sebuah materi kurikulum atau dokumen dianggap relevan jika sesuai dengan kebutuhan pengguna.

Prinsip relevansi kurikulum adalah prinsip relevansi artinya prinsip kesesuaian. Prinsip ini ada dua jenis yaitu, relevansi internal (internal relevance) dan relevansi eksternal (external relevance). Prinsip relevansi kurikulum ada empat jenis: pertama relevansi pendidikan dengan lingkungan anak didik. Kedua, relevansi pendidikan dengan kehidupan yang akan datang. Ketiga, relevansi pendidikan dengan dunia kerja. Keempat, relevansi pendidikan dengan ilmu penegetahuan (Idi, 2011). Prinsip relevansi dalam pendidikan adalah kemampuan pendidikan dalam menyesuaikan dengan perkembangan dunia luar pendidikan dan kemampuan menyesuaikan antara komponen pendidikan dalam mencapai tujuan.

\section{METODE PENELITIAN}

Metode yang digunakan pada penelitian ini adalah metode evaluasi dengan model discrepancy. Kesesuaian komponen materi pembelajaran dari kurikulum untuk mencapai tujuan DPTM (menyiapkan tenaga pendidik yang profesional), dapat dilihat dengan melihat tingkat kesenjangan antara materi pembelajaran DPTM dengan materi pembelajaran SMK dan materi UKK, yaitu dengan menggunakan metode evaluasi model discrepancy. Model kesenjangan/discrepancy merupakan model yang luwes karena dapat, dan bahkan harus digunakan pada semua jenis evaluasi. Tahapan penelitian yang dilakukan sebagai berikut: 


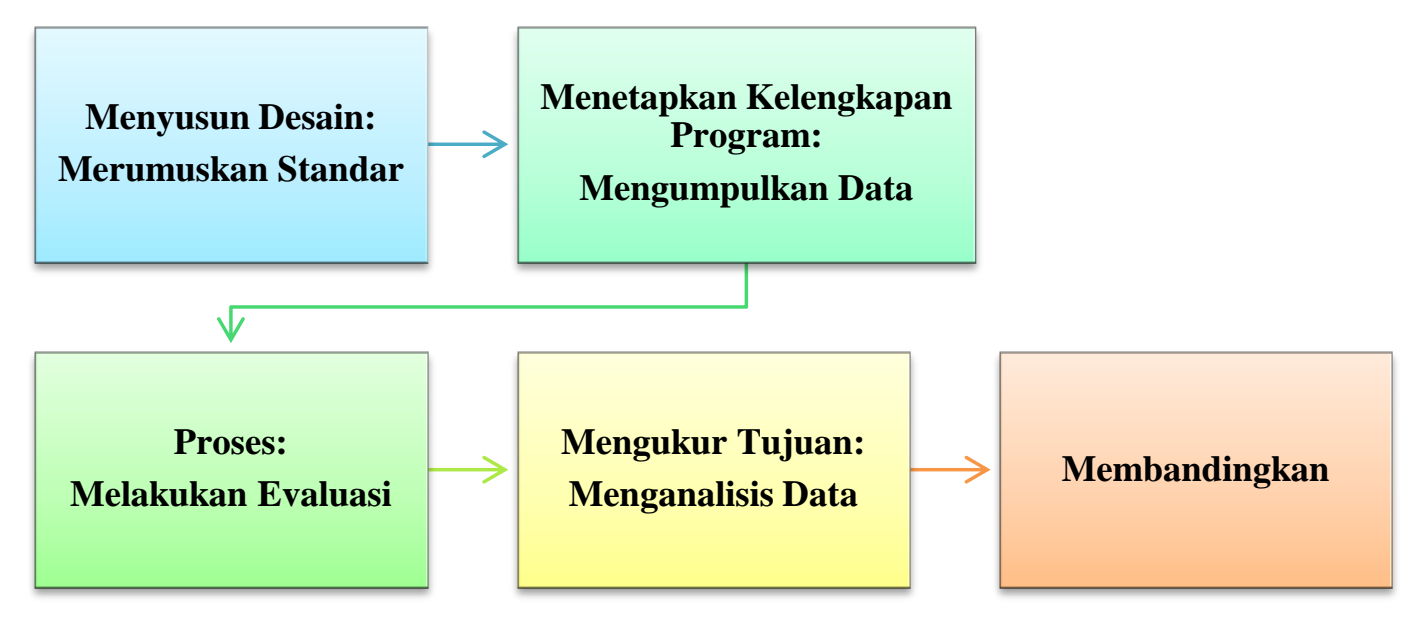

Gambar 1. Alur Penelitian

\section{HASIL PNELITIAN}

Materi mata kuliah keahlian otomotif terdiri dari 102 materi (materi kelistrikan otomotif I terdiri dari 21 materi, kelistrikan otomotif II terdiri dari 11 materi, chassis otomotif terdiri dari 31 materi dan power train otomotif terdiri dari 39 materi). Materi mata pelajaran kompetensi keahlian teknik kendaraan ringan, terdiri dari 173 materi (materi kelistrikan TKR terdiri dari 11 kompetensi dasar, mencakup 92 materi, chassis dan power train TKR terdiri dari 11 kompetensi dasar, mencakup 81 materi). Adapun relevansi yang diperoleh dari hasil pengisian angket tertutup (Gambar 2).

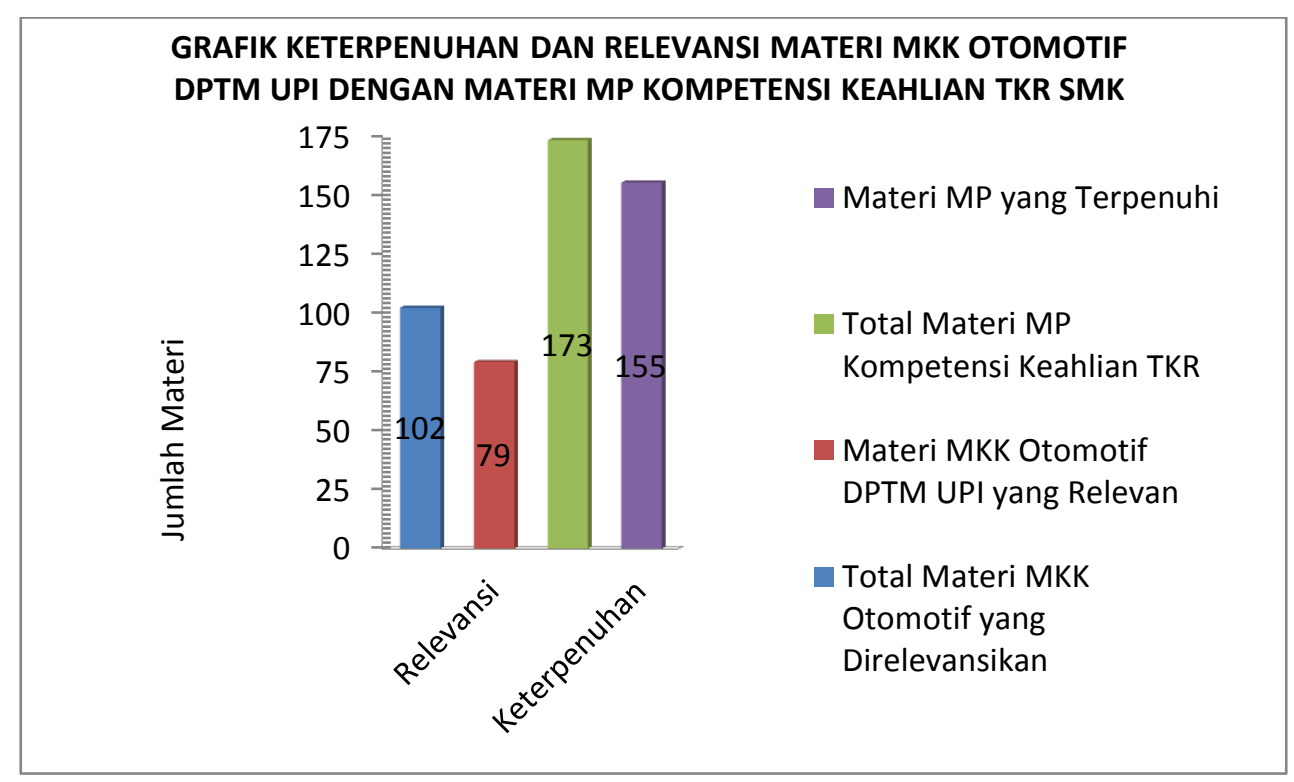

Gambar 2. Grafik Relevansi Materi MKK Otomotif DPTM UPI dengan Materi MP Kompetensi Keahlian TKR SMK

Jumlah materi MKK Otomotif yang relevan dengan materi MP Kompetensi Keahlian TKR sebanyak 79 materi dari 102 materi yang ada di MKK Otomotif. 
Kebanyakan dari materi-materi yang tidak relevan adalah materi-materi tambahan dan pendalaman teori perhitungan. Jumlah keterpenuhan materi MP Kompetensi Keahlian TKR oleh materi MKK Otomotif, terlihat bahwa dari 173 materi MP Kompetensi Keahlian TKR yang ada di SMK, terdapat 155 materi yang terpenuhi, dan terdapat 18 materi yang tidak terpenuhi. Materi mata kuliah kelistrikan otomotif I dan II memang tidak termasuk, karena Sistem EFI dan Sistem EMS adalah materi yang termasuk kedalam materi Mata Kuliah Kontrol Elektronik, dan Sistem GDI adalah materi yang termasuk ke dalam materi mata kuliah motor bensin. Dengan demikian, sebenarnya materi MP Kelistrikan TKR, telah tercakup oleh materi MK Konsentrasi Otomotif.

Materi mata kuliah keahlian otomotif terdiri dari 102 materi (Materi Kelistrikan Otomotif I terdiri dari 21 materi, Kelistrikan Otomotif II terdiri dari 11 materi, Chassis Otomotif terdiri dari 31 materi dan Power Train Otomotif terdiri dari 39 materi). Materi Uji Kompetensi Keahlian BSNP Teknik Kendaraan Ringan (TKR) terdiri dari tiga paket, yaitu Paket I terdiri dari 33 materi (Engine Bensin terdiri dari 21 materi, Power Train terdiri dari 6 materi, dan Kelistrikan Bodi terdiri dari 6 materi), Paket II terdiri dari 64 materi (Engine Diesel 21 materi, Chassis 23 materi, dan Kelistrikan 20 materi), Paket III terdiri dari 53 materi (Engine Bensin EFI terdiri dari 34 materi, Chassis terdiri dari 13 materi, dan Kelistrikan terdiri dari 6 materi). Relevansi yang diperoleh dari hasil pengisian angket tertutup (Gambar 3).

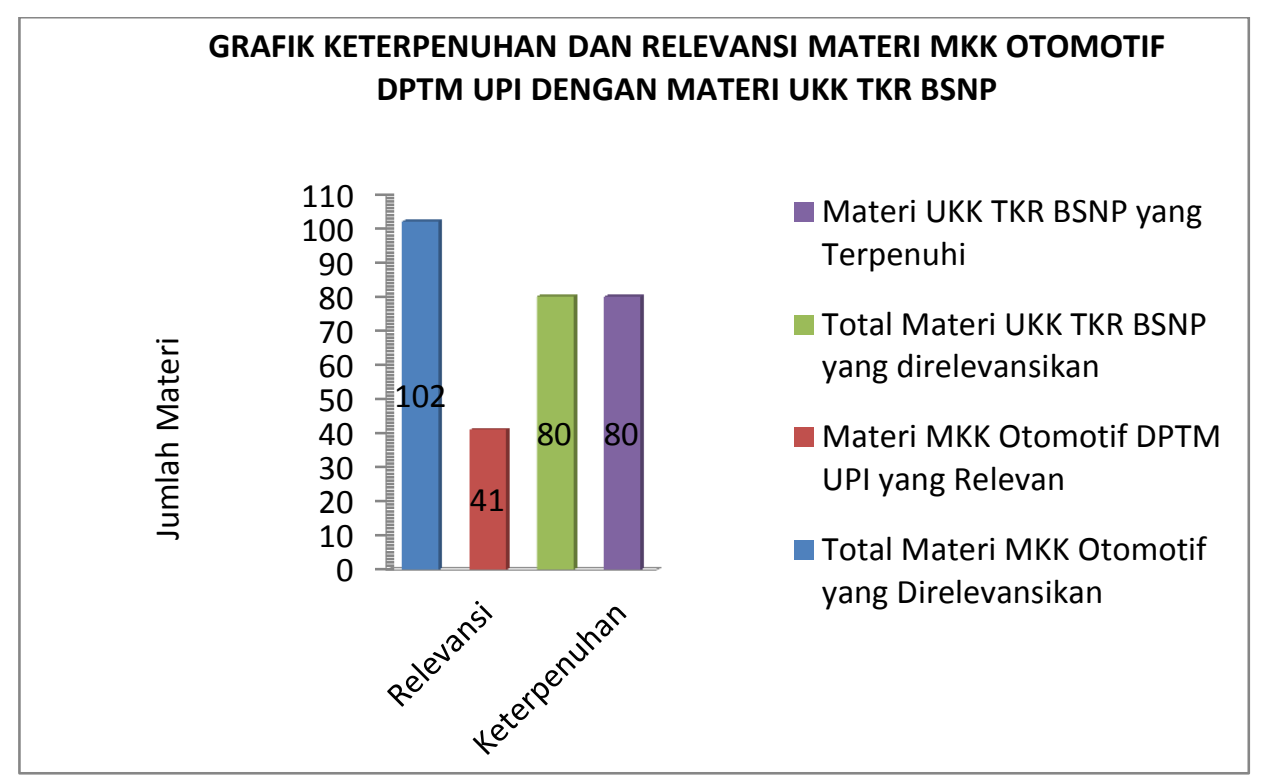

Gambar 3. Grafik Relevansi Materi MKK Otomotif DPTM UPI Terhadap Materi UKK TKR BSNP 
Jumlah materi MKK Otomotif yang relevan dengan materi UKK TKR BSNP sebanyak 41 materi dari 102 materi yang ada di MKK Otomotif, materi yang tidak relevan adalah materi yang tidak diujikan dalam UKK TKR BSNP. Jumlah materi UKK TKR BSNP yang terpenuhi, yaitu dari 80 materi yang direlevansikan, kesemuanya terpenuhi, yaitu materi Kelistrikan (Kelistrikan Bodi, Perawatan Sistem Starter, dan Perawatan Sistem Pengisian), materi Power Train (Transmisi Manual), dan materi Chassis (Pengukuran Spooring/FWA, Mem-balance Roda, dan Perawatan Sistem Rem). Dengan demikian, materi MKK Otomotif telah Relevan dan Memenuhi kebutuhan materi UKK TKR BSNP.

Materi Mata Pelajaran Kompetensi Keahlian TKR terdiri dari 200 materi (Materi kelistrikan teknik kendaraan ringan terdiri dari 92 materi, Chassis dan Power train teknik kendaraan ringan terdiri dari 81, dan Engine teknik kendaraan ringan terdiri dari 27 materi). Materi Uji Kompetensi Keahlian BSNP Teknik Kendaraan Ringan (TKR) terdiri dari tiga paket, yaitu Paket I terdiri dari 33 materi (Engine Bensin terdiri dari 21 materi, Power Train terdiri dari 6 materi, dan Kelistrikan Bodi terdiri dari 6 materi), Paket II terdiri dari 64 materi (Engine Diesel 21 materi, Chassis 23 materi, dan Kelistrikan 20 materi), Paket III terdiri dari 53 materi (Engine Bensin EFI terdiri dari 34 materi, Chassis terdiri dari 13 materi, dan Kelistrikan terdiri dari 6 materi). Relevansi yang diperoleh dari hasil pengisian angket tertutup (Gambar 4).

Jumlah materi MKK Otomotif yang relevan dengan materi UKK TKR BSNP sebanyak 101 materi dari 200 materi yang ada di MP Kompetensi Keahlian TKR, materi yang tidak relevan adalah materi yang tidak diujikan dalam UKK TKR BSNP. Jumlah materi UKK TKR BSNP yang terpenuhi, yaitu dari 150 materi yang direlevansikan, belum kesemuanya terpenuhi, masih terdapat 10 materi yang tidak terpenuhi, yaitu dari materi Engine (Engine Bensin, Engine Diesel, dan Engine Bensin EFI), materi Kelistrikan (Kelistrikan Bodi, Perawatan Sistem Starter, dan Perawatan Sistem Pengisian), Materi Power Train (Transmisi Manual), dan Materi Chassis (Pengukuran Spooring/FWA, Membalance Roda, dan Perawatan Sistem Rem), pada materi Engine Bensin EFI, 10 materi belum terpenuhi, yaitu materi Overhaul Engine Bensin EFI. Dengan demikian, materi materi MP Kompetensi Keahlian TKR telah relevan, namun belum memenuhi kebutuhan materi UKK TKR BSNP sepenuhnya. 


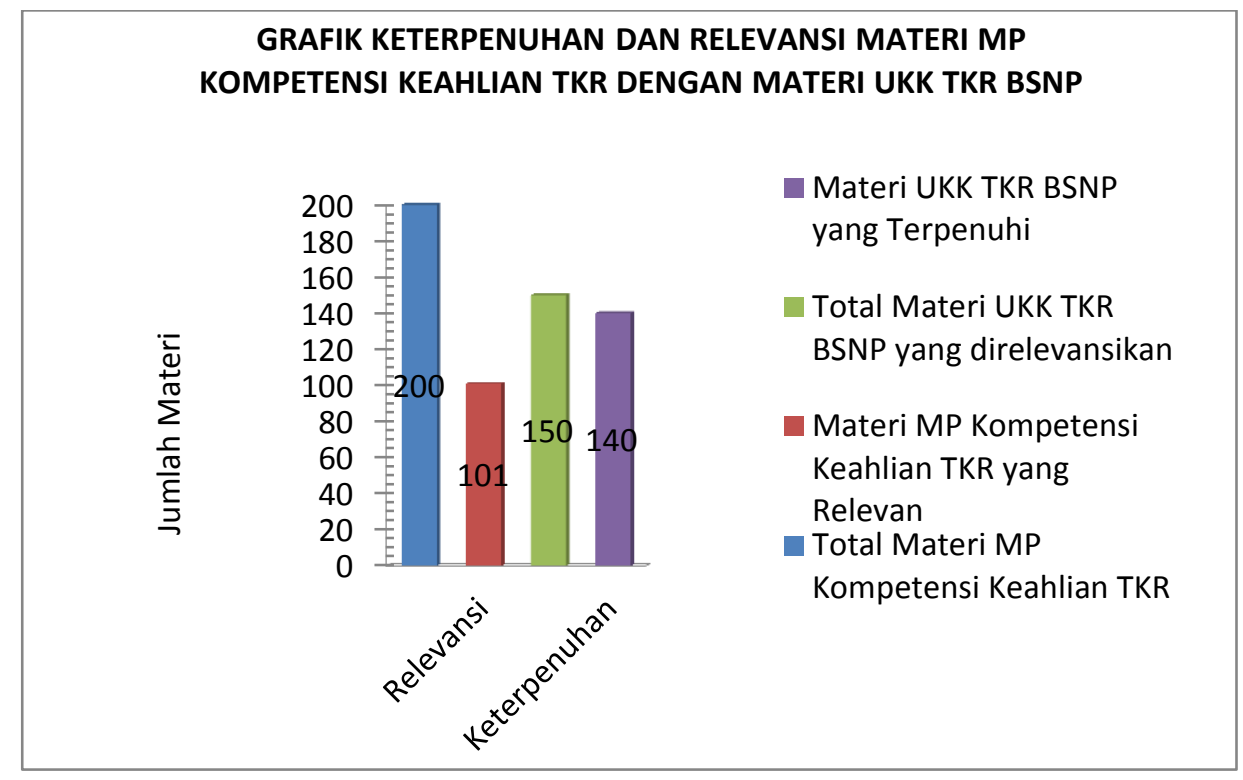

Gambar 4. Grafik Relevansi Materi Mata Pelajaran Kompetensi Keahlian TKR Terhadap Materi UKK TKR BSNP

\section{PEMBAHASAN}

Masih terdapat materi mata kuliah keahlian otomotif yang tidak relevan. Kebanyakan dari materi-materi tersebut adalah materi-materi tambahan dan pendalaman teori perhitungan. Sedangkan di SMK, teori perhitungan yang lebih mendalam tidak diberikan karena tidak diperlukan bagi tingkat SMK. Sesuai dengan tujuan paket keahlian khususnya teknik kendaraan ringan pada draf kurikulum SMK Negeri 8 Bandung, yaitu mampu dalam melakukan pekerjaan pemeliharaan baik Engine, Sistem Pemindah Tenaga dan Chasis serta kelistrikan teknik kendaraan ringan yang fokus untuk menghasilkan tenaga mekanik yang baik dan siap. Sesuai dengan salah satu fungsi kurikulum, yaitu fungsi suplementasi. Materi-materi tambahan dan pendalaman secara teori menjadi tambahan wawasan lebih bagi mahasiswa yang mengambil mata kuliah tersebut, sesuai dengan tuntutan kompetensi profesional tenaga pendidik yang terdapat dalam UndangUndang Guru dan Dosen, berlaku juga bagi calon pendidik yang sedang dalam tahap membekali diri menjadi pendidik yang profesional.

Ada materi MP kompetensi keahlian TKR yang tidak terpenuhi, yaitu 1) Sistem Bahan Bakar Injeksi Bensin (EFI), 2) Sistem Engine Manajemen (EMS), dan 3) Sistem Gasoline Direct Injection (GDI). Sistem EFI dan Sistem EMS adalah materi yang termasuk kedalam materi Mata Kuliah Kontrol Elektronik otomotif. Sistem GDI adalah materi yang termasuk kedalam materi Mata Kuliah Motor Bensin. Hal ini sesuai dengan prinsip umum pengembangan kurikulum relevansi internal. Dapat diartikan bahwa terdapat keterkaitan dan mendukung antar materi pembelajaran. Materi MP Kelistrikan TKR, telah 
terpenuhi oleh materi MK Keahlian Otomotif. Artinya bahwa materi Mata Pelajaran Kompetensi Keahlian TKR telah terpenuhi seluruhnya, oleh materi Mata Kuliah Keahlian (MKK) Otomotif. Dengan kata lain, materi MKK Otomotif telah memenuhi prinsip relevansi eksternal dengan SMK (Winoto dan Komariah, 2012).

Materi UKK TKR BSNP yang direlevansikan telah terpenuhi seluruhnya oleh materi MKK Otomotif. Dengan demikian, materi pembelajaran yang digunakan MKK Otomotif (Kelistrikan Otomotif, Power Train Otomotif, dan Chassis Otomotif) telah mendukung dalam upaya mewujudkan salah satu misi DPTM menyiapkan tenaga pendidik yang profesional dan berdaya saing global. Materi kurikulum dikembangkan dan disusun guna mencapai tujuan. Materi pembelajaran yang relevan dan mampu memenuhi kebutuhan pengguna adalah salah satu dasar untuk menyiapkan tenaga pendidik yang profesional. Semua materi penyusun kurikulum berisi tentang pengalaman yang harus dimiliki peserta didik dibawah pengawasan guru. Pengalaman belajar inilah yang akan menjadi bekal bagi calon pendidik untuk melaksanakan tugasnya sebagai pendidik di sekolah (SMK). Pendidik/guru di sekolah memiliki peran yang cukup menentukan. Apakah materi yang telah disusun dengan baik mampu tersampaikan kepada peserta didik atau tidak. Peran guru amat signifikan bagi setiap keberhasilan proses pembelajaran, maka penting bagi calon pendidik memiliki bekal yang cukup.

Materi UKK TKR BSNP belum terpenuhi oleh MP Kompetensi Keahlian TKR seluruhnya. Berdasarkan cakupan materi untuk materi UKK TKR BSNP, 10 materi yang tidak terpenuhi termasuk dalam materi Overhaul Engine Bensin EFI. Mengingat UKK adalah salah satu syarat bagi peserta didik SMK dinyatakan lulus seperti yang tertera pada Permendiknas Nomor 28 Tahun 2009. Penting bagi pihak SMK untuk mempertimbangkan penambahan materi Overhaul engine Bensin EFI di dalam kurikulum yang digunakan. Selain itu teknologi EFI saat ini adalah teknologi yang digunakan di semua kendaraan ringan. Peserta didik SMK keahlian TKR, dituntut harus mampu melakukan pekerjaan perbaikan pada engine yang berteknologi EFI. Hal ini merupakan tuntutan kebutuhan masyarakat yang harus mampu dipenuhi oleh SMK. Sesuai dengan salah satu peran kreatif kurikulum. Kurikulum berperan untuk menciptakan dan menyusun kegiatan yang kreatif dan konstruktif sesuai dengan perkembangan peserta didik dan kebutuhan masyarakat. Prinsip relevansi eksternal atau kurikulum harus sesuai dengan tuntutan dan kebutuhan masyarakat dan dunia kerja. 


\section{KESIMPULAN}

Kesimpulan penelitian ini yaitu materi MKK Otomotif DPTM UPI sudah relevan dengan materi MP Kompetensi Keahlian TKR SMK. Materi Mata Pelajaran Kompetensi Keahlian TKR terpenuhi seluruhnya oleh materi MKK Otomotif. Materi MKK Otomotif DPTM UPI sudah relevan dengan materi UKK TKR BSNP. Materi UKK TKR BSNP terpenuhi seluruhnya oleh materi MKK Otomotif DPTM UPI. Materi MP Kompetensi Keahlian TKR SMK Negeri 8 Bandung belum memenuhi materi UKK TKR BSNP seluruhnya.

\section{DAFTAR PUSTAKA}

Arifin, Z. (2011). Konsep dan Model Pengembangan Kurikulum. Bandung: Remaja Rosdakarya.

Dakir. (2010). Perencanaan dan Pengembangan Kurikulum. Jakarta: Rineka Cipta.

Hamalik, O. (2007). Dasar-Dasar Pengembangan Kurikulum. Bandung: Remaja Rosdakarya.

Idi, A. (2011). Pengembangan Kurikulum: Teori dan Praktik. Jogjakarta: Ar-Ruzz Media.

Munir. (2010). Kurikulum Berbasis Teknologi Informasi dan Komunikasi. Bandung: Alfabeta.

Nasution, S. (2003). Pengembangan Kurikulum. Bandung: Citra Aditya Bakti.

Sanjaya, W. (2008). Perencanaan dan Desain Sistem Pembelajaran. Jakarta: Kencana Prenada Media Group.

Sukmadinata, N. S, (2009). Pengembangan Kurikulum: Teori dan Praktek. Bandung: Remaja Rosdakarya.

Winoto, Y. \& Komariah, N. (2012). Meninjau Relevansi Kurikulum Pendidikan llmu Perpustakaan dengan Kompetensi dan Sertifikasi Pustakawan. Bandung: Media Pustakawan. 